\title{
Apparent coordination of isocitrate dehydrogenase and glutamate decarboxylase expression in early stages of tree development
}

\author{
Juan Jesús Molina-Rueda', María Belén Pascual ${ }^{2}$, Lara Silvia Jiménez-Bermúdez ${ }^{3}$, Francisco Miguel Cánovas², \\ Fernando Gallardo ${ }^{2^{*}}$
}

From IUFRO Tree Biotechnology Conference 2011: From Genomes to Integration and Delivery

Arraial d Ajuda, Bahia, Brazil. 26 June - 2 July 2011

The biosynthesis of 2-oxoglutarate and glutamate are key steps in the biosynthesis of nitrogen compounds and plant development. The reaction catalyzed by cytosolic isoenzyme of NADP+-linked isocitrate dehydrogenase (IDH) is also considered as the main route in the production of 2-oxoglutarate. According to its expression pattern during development, IDH is also involved in other, yet unknown, processes [1,2]. In addition to the importance of glutamate in the biosynthesis of nitrogen compounds, glutamate also serves as precursor of GABA, a molecule that is currently considered as a signal in higher plants. GABA is produced by the action of glutamate decarboxylase (GAD), a cytosolic enzyme that is regulated by $\mathrm{Ca} 2+/$ calmodulin and $\mathrm{pH}$. In contrast to IDH, that it is encoded by just one gene in most of plant genomes [2], GAD is encoded by a small family of nuclear genes [3]. The expression of IDH and GAD has been investigated during the differentiation of hypocotyl and stem in tree species. Our results indicate a coordination of the expression of IDH and GAD in developmental processes suggesting a role for 2-oxoglutarate supply and GABA synthesis during early stages of organ differentiation in trees.

\footnotetext{
Author details

'Present address: Rutgers University, Dpt Biological Sciences, Newark, New Jersey, USA. Universidad de Málaga, Dpt. Biología Molecular y Bioquímica, Málaga, Spain. ${ }^{3}$ Universidad de Málaga, SCAl, Servicio de Cultivo de Plantas, Málaga, Spain.
}

Published: 13 September 2011

\footnotetext{
* Correspondence: fgallardo@uma.es

¿Universidad de Málaga, Dpt. Biología Molecular y Bioquímica, Málaga, Spain
} Full list of author information is available at the end of the article

\section{References}

1. Palomo J, Gallardo F, Suárez MF, Cánovas C: Purification and characterization of NADP+-linked isocitrate dehydrogenase from Scots pine. Plant Physiol 1998, 118:617-626.

2. Pascual MB, Molina-Rueda JJ, Cánovas FM, Gallardo F: Spatial distribution of cytosolic NADP+-isocitrate dehydrogenase in pine embryos and seedlings. Tree Physiol 2008, 28:1773-1782.

3. Molina-Rueda JJ, Pascual MB, Cánovas FM, Gallardo F: Characterization and developmental expression of a glutamate decarboxylase from maritime pine. Planta 2010, 232:1471-1483.

\section{doi:10.1186/1753-6561-5-S7-P66}

Cite this article as: Molina-Rueda et al:: Apparent coordination of isocitrate dehydrogenase and glutamate decarboxylase expression in early stages of tree development. BMC Proceedings 2011 5(Suppl 7):P66.

Submit your next manuscript to BioMed Central and take full advantage of:

- Convenient online submission

- Thorough peer review

- No space constraints or color figure charges

- Immediate publication on acceptance

- Inclusion in PubMed, CAS, Scopus and Google Scholar

- Research which is freely available for redistribution

Submit your manuscript at www.biomedcentral.com/submit C) Biomed Central 